There should be no difficulty, having regard to the resources of government, in having copies of the regulations available at the notified place or places at the time of notification in the gazette or at any subsequent date on which they are to become operative.

I regard the availability of the terms of the law to the citizen of paramount importance. No inconvenience in government administration can, in my opinion, be allowed to displace adherence to the principle that a citizen should not be bound by a law the terms of which he has no means of knowing. Thus, in my opinion, if it is proved that copies of the regulations were not available for purchase at the place specified, the regulations would not have commenced to operate".

[For the full opinion, see Watson \& Anor. v. Lee \& Anor., October 23, 1979. Citation not available at the time of this writing.]

\title{
PRIVACY LAW IN AUSTRALIA
}

In conjunction with its inquiry into the law of defamation, the Law Reform Commission of Australia has also examined infringements of privacy by what it terms "Unfair Publication", e.g., appropriation of a person's name, identity or likeness for the sole advantage of the publisher. The Commission has touched upon a novel concept of law in which it has attempted to balance the competing interests of individual honor, reputation and dignity with the public rights of freedom of expression and access to information.

Findings of the Commission appear in its report No. 11 entitled "Unfair Publication: Defamation and Privacy". The report is about 290 pages long. Published by the Australian Government Publishing Service, it is priced at $\mathrm{A} \$ 6.85$. Its catalog number is 7874713 .

\section{PERIODICALS SURVEY}

The Winter 1980 issue of the Computer/Law Journal (Vol. II, No. 1) is entirely devoted to a survey of electronic fund transfers in banking and other financial operations. Centering on the recent United States Electronic Fund Transfer Act, the collection of articles nevertheless reaches out beyond mere interpretative considerations of this statute. Several articles describe clearly, and yet in great detail, how electronic fund transfers operate, what are the advantages of electronic giro payments (which, without the aid of electronics, have been widely used in many European countries for a long time), and what are some of the practical implications of changing from a conventional check (cheque) payment 
system to direct electronic transfers. All of this is useful and not easily accessible information. A 46-page long bibliography lists predominantly United States books, articles and documents about the legal issues of electronic fund transfers systems.

The Computer/Law Journal is published quarterly by the Center for Computer/Law, 530 West Sixth Street, Los Angeles, California 90014, U.S.A. Annual subscription is U.S. \$54 (U.S. \$58 outside the United States). Single issues are priced at U.S. $\$ 16$ (U.S. $\$ 17$ outside the United States).

\section{NEW BIBLIOGRAPHIES}

Interesting, if not always satisfactorily comprehensive, bibliographies on different subjects related to international law are published by Gale Research Company within its International Relations Information Guide series. The two most recent volumes in the series (Volume 8 and 9 respectively) contain useful information for researchers not only in the United States, but also in other countries.

The International Relations of Eastern Europe: $A$ Guide to Information Sources. Edited by Robin Alison Remington. Detroit, Michigan: Gale Research Company, 1978. Pp. xvi, 273. U.S. $\$ 22.00$.

This work, Volume 8 in the series, is a comprehensive bibliography of books, articles and other writings pertaining to Eastern Europe. It is divided into two major sections. The first, "Eastern Europe as a Region," is divided into chapters such as "Comparative Approach," "Historical Approach," and "The Warsaw Treaty Organization (WTO)." The second, "County-Specific Sources," identifies and describes sources relating to Albania, Bulgaria, Czechoslovakia, East Germany, Hungary, Poland, Rumania, and Yugoslavia. Many of the entries are annotated or accompanied by explanatory abstracts.

The European Communities; $A$ Guide to Information Sources. By J. Bryan Collester. Detroit, Michigan: Gale Research Company, 1979. Pp. xxxii, 265. U.S. \$22.00.

This annotated and categorized bibliography, representing Volume 9 in the series, lists some 1400 books, pamphlets, and dissertations principally concerned with the political aspects of European integration. The introduction is in the form of a bibliographical note examining the most significant sources of literature in each of the substantive chapters of the bibliography: theoretical and conceptual studies of integration; general, historical, and institutional studies of integration; background and policy 